Special Section on Action Research

\title{
What to do about the boys? Advocating for system change when doing social justice work with girls
}

\author{
Britney G Brinkman \\ Chatham University \\ Kandie G. Brinkman \\ University of Utah \\ Shannon Toomey \\ Chatham University
}

\begin{abstract}
Girls' Studies has been a quickly growing field, which has included work focused on interventions designed to improve the lives of girls. Programs have been developed and utilized to address eating disorders and body image concerns, self-esteem, access to math and science mentors, experiences of sexism, and others. In this paper, we describe a social justice intervention designed to recognize and increase girls' resiliency. First, we provide a brief overview of current research and programming with girls and boys to provide a context for the intervention and the challenges that arose. Next, we describe how we navigated within a school system, managed mixed support from school personnel, and addressed male students' backlash about the girls' participation in the program. We include information from workshops and interviews with the adolescent girls to highlight their voices regarding their experiences of interpersonal sexism with their male classmates. We conclude with three key lessons we learned from this work, including the need to: address the systems in which girls live, consider the implications of an "empowerment" model, and anticipate possible areas of resistance. We pose these lessons in the hopes that we can contribute to dialogues amongst researchers, counselors, and scholars who are engaged in social change work and face challenges or barriers that may arise while doing this work.
\end{abstract}

Keywords. action research, girls, boys, resiliency, empowerment 


\section{Interventions with Girls}

Girls' Studies emerged as a field in the early 1990's (Kearney, 2009). Before that time, examination of girls specifically was often ignored within academia as girls were neglected in discussions of women's issues while youth scholars focused primarily on boys. There are a number of reasons for this oversight and reasons why girls began to gain attention in the 1990's (see Kearney, 2009 for a thorough investigation of the development of Girls' Studies as a discipline). As the field of women's studies gained legitimacy and the number of feminist scholars increased, questions were raised about the lack of focus on girls. Within psychology, concerns were raised about the challenges girls faced and the struggles they overcame. Scholars like Gilligan (1982) and Pipher (1994) described how girls lost their voice and suffered from low self-esteem. Girls themselves joined the conversations, reminding scholars to look beyond girls as simply consumers or victims and to recognize their power, potential, and strengths (Findlen, 1995; Jacob, 2002; Shandler, 1999; Hinshaw, 2009). Current trends within Girls' Studies include recognizing global diversity and intersections of identity (Kearney, 2009), addressing the needs of "tween" girls (Mitchell \& Reid-Walsh, 2005), and including girls as coauthors (e.g. Jiwani, Steenbergen, \& Mitchell, 2006). In this paper, we describe the intervention we developed for adolescent girls, their experiences of backlash from their male classmates, our attempts to respond to this backlash, and the lessons we learned from this work. In particular, we explore how we conceptualized and addressed the need for system change when conducting action research with adolescent girls.

Part of the movement towards Girls' Studies was based on growing concerns about girls' wellbeing, and programs were developed with the hopes of improving the lives of girls. These interventions have differed in the extent to which they address the necessity of system change. Many of the early programs were based on the concerns of counselors and therapists, like Mary Pipher (1994), who were working with girls who had low self-esteem, were suffering from eating disorders, and were experiencing difficulties in relationships. These types of programs highlight ways individual girls can better cope with or adjust to stressors. For example, Girl Power! (SAMHSA, 1999) focuses on enhancing girls' mental well-being by emphasizing the development of interpersonal and social skills, encouraging girls to develop interests in academics and sports, and educating girls about the risks associated with eating disorders and substance abuse. This approach to working with girls often places them in the role of potential "victim" to life stressors and does not address the need for changes in the social system.

Other programs examine cultural factors influencing girls, but may not explicitly advocate for system change. For example, Rosalind Wiseman's program "Owning Up" addresses the role of socialization of girls (and boys) and how gender roles may impact behavior and encourages girls to "take responsibility to treat themselves and others with dignity" (Wiseman, n.d.). Many such programs are interested in "empowering" girls - suggesting that perhaps the problem is that girls do not have sufficient power and that the solution is to give them more power. Ristock and Pennell (1996) describe this as an individual or interpersonal form of empowerment in which one draws on inner strength to assert themselves or to share resources and work collaboratively with others to accomplish goals. This approach does not necessarily address what happens if individuals become empowered but continue to exist in a system of complex interlocking institutions such as education, media, and ideologies, which has not changed. 
Some feminist scholars have questioned the limitations of the "girl power" paradigm and argue for the need to further explore ways to work toward system change (Currie, Kelly, \& Pomerantz, 2009). Such researchers advocate for the importance of societal empowerment which has a social change agenda focused on "changing the nature and distribution of power in our society" (Ristock \& Pennell, 1996, p.2). For example, Lyn Michael Brown (co-founder of Hardy Girls Healthy Women http://www.hardygirlshealthywomen.org/) has challenged the "girl as victim" model (2003) and asserts that girls be seen as active agents in their own lives, navigating within a patriarchal system which provides them with limited options. She and her colleagues argue that problems impacting girls (such as violence and sexual harassment) and their potential solutions must be viewed within the context of patriarchy (Brown, Chesney-Lind, \& Stein, 2007). This approach to interventions for girls is explicit about the need for system change.

\section{What About the Boys?}

Most of the approaches to work with girls have not specifically examined the role boys play in the gendered experience of girls. However, in order to advocate for system change when doing work with girls, it is important to understand what is happening in the lives of boys and how this influences girls' experiences. While there has yet to develop a distinct Boys' Studies discipline, there has been a growing body of literature examining boys' experiences as gendered beings. Much of this scholarship developed around the same time that research about girls began, but usually happened in a parallel or a reactive fashion (often with concerns about boys increasing in response to work designed to assist girls). While this research identifies the potentially harmful impact, privilege has on boys' experience of gender; it also provides greater understanding of how boys' entitlement impacts girls within the gendered system.

Similar to work with girls, scholarship on boys has varied in terms of the extent to which it addresses system change. Unfortunately, many of the early concerns about boys were raised within the context of assumptions that if more attention and care were placed on issues relevant to girls, boys would necessarily suffer. Debates began within the United States, the United Kingdom, and Australia about the place of boys; many including discussions of ways in which boys were becoming increasingly "disadvantaged" (see Foster, Kimmel, and Skelton, 2001 for a comprehensive review of these debates in all three countries). The late '90s were consumed with questions about how boys were faring in education, moral development, and psychological health. It is important to recognize that although these questions were being asked internationally, for the purposes of this paper, we will focus on the rhetoric within the United States; however, the conversations around the world have been similar. While most of the recent debates about boys have focused on concerns related to education, the last two decades have seen an increase in scholars working on issues related to boys' psychological wellbeing (see Weaver-Hightower, 2003 for a review of the "boy turn" in research).

Currently, there appear to be three general approaches to work with boys: 1) a recuperative masculinity stance conceptualizing boys as the "new disadvantaged; 2) an approach incorporating the role of gender socialization in understanding the needs of boys as individuals; and 3) a pro-feminist approach arguing for the need for system change. Much of the rhetoric about boys in the early 1990's stemmed from a recuperative masculinity stance, arguing that there was a war against boys and that boys need to have their masculine identities reaffirmed (Foster, Kimmel, \& Skelton, 2001; Lingard \& Douglas, 1999). For example, Michael Gurian 
(1996, 1998) has asserted an essentialist argument, claiming that boys are driven by testosterone to be violent, aggressive, and hyperactive, and any attempt to curb these behaviors prevents boys from being their "true selves." Gurian often takes an explicitly antifeminist stance, arguing that placing an emphasis on problems like gender discrimination and rape only humiliates boys and exacerbates problems. One of the areas in which advocates of this framework have been most vocal includes concerns about education. Recent reports have found that there are gender differences in educational enrollment and achievement when comparing all men and all women. For example, in 2008, women made up $56 \%$ of college student enrollment (NCES 2010-028). However, some research suggests that the real crisis in education is for boys and girls of color and working class families rather than for all boys as a group (e.g. AAUW, 2008; Husain \& Millimet, 2008; Lingard \& Douglas, 1999). Kimmel (2010) argues that the educational gaps between boys and girls are related to attendance, achievement, and behavior and are best understood by examining the influence of masculinity ideologies. Nonetheless, some scholars argue that boys are falling behind girls in school because feminism has led to discrimination against boys (Gurian \& Stevens, 2005). This recuperative masculinity approach does not advocate for system change because it operates from "a position of presumptive equality in respect of the broader power relations between the genders" (Lingard \& Douglas, 1999, p. 168).

The second and third approaches to understanding boys emerged in part in response to the recuperative masculinity arguments. Some authors in the late 1990 's, most notably Pollack (1998) and Kindlon and Thompson (1999), asserted that masculinity is a socialized ideology (or set of ideologies) with potentially harmful impacts on boys. This ideology often presents a culture of bravado, cruelty and isolation, and boys are socialized to be inauthentic, violent and emotionally isolated. Pollack (1998) defined the constructs of the "boy code" and the "mask of masculinity" to refer to the regulations by which boys are expected to follow and the front boys put up to hide their true emotions. This second approach emphasizes the importance of addressing gender role socialization in order to improve the lives of boys. In many ways, this approach resembles work done with girls which emphasizes individual and interpersonal forms of empowerment, and issues of system change are often not explicitly addressed.

The third, pro-feminist, approach has been advocated by scholars focused on social justice. Boys' programs based on this approach are intended to "complement feminist work with girls in order to build just and equitable social and personal relationships" (Lingard \& Douglas, 1999, p.141). For example, Salisbury and Jackson's (1996) work challenges traditional masculinity and the "boys will be boys" model, arguing that programs for boys must explicitly address patriarchy. The activist and founder of the Oakland Men's Project, Paul Kivel (1999) argued that boys should be raised to challenge racism, sexism, and homophobia and asserts that boys' programs should directly confront male privilege. This approach addresses the need to discuss the systems in which boys and girls live and interact. One area in which a number of programs have emerged is in regards to work engaging men and boys in the prevention of violence against women (e.g. Crooks, Goodall, Hughes, Jafe, \& Baker, 2007; Fabiano, Perkins, Berkowitz, Linkenbach, \& Stark, 2003). A social norms approach and a cognitive behavioral approach have been applied to developing programs to increase boys' and men's motivation as allies in ending violence against women. These types of programs recognize the potential power that boys and men have within society and address how they can use their power to be allies for change. This third approach to work with boys emphasizes acknowledging and challenging the systems impacting boys (ranging from educational systems to patriarchy). 


\section{The Need for System Change to Achieve Social Justice for Girls}

What do we mean when we say "system change?" The girls in this study belong to a number of systems and are impacted by the ways in which they function. For example, the educational system defines intelligence and learning in specific ways. The girls in this study attended a Catholic school in particular, which was influenced by teachings and beliefs of the Catholic Church. The girls were from a variety of ethnic, cultural, and economic backgrounds and were likely impacted in specific ways by systems related to these areas of identity (e.g. through experiences of racism and classism). Although an exploration of all of the complexities of the social systems girls and boys live within is outside the scope of this paper (see Bronfenbrenner, 1977; Kelly, 1970; Trickett, Kelly, \& Vincent, 1985 for discussions of multiple level systems), it is important to examine how the system of patriarchy impacts both girls and boys. Allen Johnson (2005) defines patriarchy as a system that allows men to "dominate women as a kind of compensation for being subordinate to other men because of social class, race, and other forms of inequality" (p.37). It is within this system that boys and girls develop their sense of a gendered self, and girls learn to fit into a devalued status while boys learn an entitlement to patriarchal privilege. Gilligan's (1997) work examined how girls lose confidence during the "tween" years, and Pollack's (1998) work focuses on how boys become overly confident - often in inauthentic and dangerous ways. Boys expect to take up more space, and girls give it up, "As girls lose confidence, boys seem to gain it" (Foster, Kimmel, \& Skelton, 2001, p. 13). Boys and girls are socialized to behave according to the assumptions of patriarchy, a system which does not always benefit its members.

One recent approach to changing the system has been to develop co-ed interventions addressing issues of gender and prejudice. These types of programs have had some success in reducing gender prejudice amongst children. For example, in a study by Rainey and Rust (1999), 36 kindergarteners from a rural area participated in Thomson's "Words Can Hurt You" program. The children learned about gender discrimination and gender stereotypes and demonstrated some reduction of stereotyping after participating in the program. Lamb, Bigler, Liben, and Green (2009) found that children who participated in a school intervention were more likely to challenge their peers' sexist comments than before the intervention. Similarly, elementary school boys and girls who participated in a program to teach them about social justice engaged in significantly less gender prejudiced behaviors towards their peers when compared to a control group (Brinkman, Rosén, Zimmerman, \& Jedinak, 2010). Unfortunately, there has been little discussion in the literature of when to utilize integrated versus single sex social justice programming, and additional research is needed in this area.

Taking a system change approach to interventions for girls is about the theoretical orientation used to do the work - not just the targets of the intervention. Involved in this theoretical orientation are questions about how to define the problem and what needs to change. Regardless of whether single sex or co-ed programming (or a combination of the two) is used, we believe that these programs must be provided within a context which recognizes that girls and boys are impacted by the systems in which they live (ranging from their classroom to patriarchy) and that these systems can be changed.

When patriarchy is viewed from an essentialist framework - being understood as natural and inevitable - the assumption is that the system is unchangeable (see Kramer, 2011; Johnson, 2005; Newman, 2007 for further analyses of patriarchy). This ideology often leads to the 
problematic assertion that "boys will be boys" and places girls in the role of victim. It is within this framework that programs emerge which focus on changing individual boys/girls. However, when one does not view patriarchy as an inevitable system, but rather as a social construction, the possibility for change arises. From this theoretical framework, the focus of programming becomes shifting the systems and empowering girls (and boys) to be part of the change. Such programs address socialized gender ideologies and their limitations, education about patriarchy, examinations of how systems function (not just individuals), as well as conversations about how and why children engage in and how they can challenge gender prejudice (as well as racism, homophobia, and other forms of prejudice connected to patriarchy). Simply asking girls to change the way they deal with sexism is insufficient. Within a system change approach, it is not individual girls or boys who are the problem or target of change, but systems which empower some at the expense of others and promote restrictive and limiting ideologies.

\section{Research Study and Intervention}

\section{Orientation to research and research methods}

The research/intervention program was developed utilizing principles of participatory action research (PAR) and employs a mixed methods design, integrating qualitative and quantitative research methods. Kidd and Kral (2005) describe the necessary elements of action research as mutual involvement by researchers and participants, commitment to work for social change, and promotion of personal growth. Action research is especially appropriate for studies promoting social change, such as our work with adolescent girls. PAR researchers explicitly address cultural and socioeconomic factors and establish working relationships with the participants (Ditrano \& Silverstein, 2006). Consistent with the principles of action research, our goal was not to simply "study" the girls as if they were non-active subjects, but rather to involve them in the process of gathering new knowledge. We also utilized a social constructivist perspective (Freeman \& Mathison, 2009) which argues that participants are actively involved in constructing their own realities and should thus be involved in the research process. Both PAR as a method and a social constructivist perspective emerged from grounded theory; a qualitative research approach (Glaser \& Strauss, 1967). Consistent with the principles of both PAR and a social constructivist perspective, we included the young women as active agents in the research process.

The study is an eight-year longitudinal project intended to follow the girls from the beginning of their sixth grade year through their first year post-high school. Based on the findings of a pilot study we conducted with high school seniors (Brinkman \& Brinkman, 2004), we developed a series of workshops in order to increase the resiliency of young women experiencing sexism. We examined how self-esteem, along with other variables influencing resiliency, was impacted by the girls' experiences of sexism. Each year the girls participated in four workshops focusing around a yearly theme (see below for more info about the first year's workshops). The girls participated in interviews at the end of each year.

\section{Community and Participant Characteristics}

This project took place at a small K-8 Catholic School within the Western United States. While a thorough discussion of the political dynamics involved in this location are beyond the scope of this article, it is important to understand the context in which this research took place. The 
particular school is small, with only one class of each grade, with each class consisting of about 20-30 students. The Catholic school is overseen by the diocese, which has final say in programming and curriculum. The authors approached the principal of this school and described their interest in developing a social justice curriculum for young girls in order to increase their resiliency. The principal of the school was very enthusiastic about participating, and shared her ideas/thoughts about what would be helpful for the girls in her community. The principal became an active agent within the program, and the researchers met with her regularly to provide updates about the program and receive feedback and share ideas. The investigators received approval from the Institutional Review Board and approval from the Catholic Diocese.

The demographics of this particular school were more diverse in terms of ethnicity and socioeconomic status than most of the other Catholic schools in this diocese. The class with which we worked had a ratio of 2:1 males to females. All of the girls in the $6^{\text {th }}$ grade class $(N=$ 11) were invited to participate in the intervention and research program and were given parental permission forms and assent forms. The parents of all of the girls agreed to participate. At the time of enrollment, all girls were in $6^{\text {th }}$ grade, with a mean age of 11.3 years. The girls were from a variety of ethnic backgrounds and identified as being African American $(N=1)$, American Indian $(N=1)$, Asian $(N=1)$, White non-Hispanic $(N=4)$, Hispanic $(N=2)$, or multi-ethnic $(N=2)$. All of the girls reported that both their mothers and fathers had completed at least some college, with four mothers and fathers having four-year college degrees and two mothers and fathers having graduate degrees.

\section{Workshops and Data Collection}

The goal of the workshops the first year was to introduce the girls to relevant constructs (e.g. sexism, gender, discrimination, socialization) and the purpose of the overall program. Studies (Bigler, 1999; Tolman and Porche, 2000; Turner, Norman, \& Zunz, 1995) have suggested that when girls understand sexism and discrimination, they are better equipped to cope with potential experiences of gender prejudice. In this program, our goal was to support girls' resiliency by helping them develop tools to cope with and conceptualize sexism. In this case, we were fortunate enough to enter a pre-built community as most of the girls had been going to school together for a number of years. We did some icebreaking exercises to build community and create relationships between the girls and the researchers. (If we had been working with a group of girls who did not know each other, we would have spent more time addressing community building.)

During the first workshop, the girls discussed definitions of sexism and began to discuss experiences they had with discrimination. The girls were each given a notebook in which they were instructed to journal about experiences with sexism that we would discuss during each workshop. The second workshop focused on how their identity was influenced by gender constructs. The third workshop explored gender role stereotypes, and the social mechanisms that reward girls and boys to conform or punish them for non-conformity. The final workshop tied together what the girls had learned that year, asked for their input about the workshops, and asked them what they would like to focus on for the next year. 


\section{Girls' Experiences with Male Classmates and Researcher Response}

\section{Girls' Experiences of Interpersonal Sexism}

In this paper, we discuss in depth some of the girls' experiences of backlash from the boys in their class. However, it is important to note that these experiences were not isolated, but rather part of a larger pattern of interpersonal sexism taking place within the classroom. In fact, during the interviews at the end of the $6^{\text {th }}$ grade year, the girls discussed their interactions with their male classmates, describing experiences of exclusion, sexual harassment, and hearing degrading comments from their male classmates. Five of the girls reported about their experiences being excluded from sports activities by boys in their class. One girl commented, "One time I wanted to play football and they said no because I was a girl." Other girls reported that the boys would let them play, but only reluctantly, "I always play softball with the boys. Well, lots of sports with them. And I'm always picked last because I'm a girl, and it makes me feel bad because I can be at least as good as everyone else in sports." The girls commented that even when they are allowed to participate in the game (sometimes because the boys were forced by teachers to include the girls), the boys often did not engage with them or include them to the same degree as their male peers. "... playing football with the boys outside. They never really pass to you ...because you are a girl..." Even when the girls were included in the game, the boys sometimes treated the girls as if they were less competent, "Ok, we were playing kickball one time and they always do it slow for us..." Unfortunately, many of the girls indicated that there was a group mentality amongst their male peers to not include them. In one example reported by a participant, she approached one boy in the class, asking him if she could play football with them, "I asked one person and then they started to say yes but then the whole team was like no, no, no!"

While experiences of exclusion were the most common type of gender discrimination reported by the girls, they also indicated that their male peers would call them derogatory names. One girl said, "the boys in our class are pretty bad at that [calling the girls 'slut']. They will call you it like three times a day at least." Other girls indicated experiencing sexual harassment from the boys in their class, "one time some boys in my class had this stick, and they poked me in the butt and they kept teasing me." One girl indicated her general perception that the boys intended to be hurtful to the girls. When asked if she acts any differently around the boys rather than with the girls in her class, she said, "Sometimes I feel kinda nervous between guys. Probably because sometimes they want to make girls feel bad and that sort of thing."

We were not surprised to hear about these interactions during the interviews, as we had been informed earlier in the year about some problems the girls were having with the boys. During the third workshop of the first year, we were informed of some negative interactions the girls were having with boys in their class. Part of the workshop outline included a check-in about the journals and an invitation for the girls to share some of their entries and discuss their experiences. At this time, the researchers were informed that many of the boys in the class had stolen the girls' journals, and the girls were afraid to use them. One girl reported that this began when one boy stole a girl's journal, saw that she had written about him as being "sexist." He mistook the word for "sexy" and was upset she was writing about him; he then ripped up her journal. The girls reported that they felt frustrated, afraid of the boys, and violated for having their journals stolen. 
The girls reported that the situation with the boys escalated beyond the stealing of the journals. They indicated that the boys taunted them about participating in the intervention and research program. They grumbled when the researchers arrived to meet with the girls and complained that it was "unfair" that the researchers brought the girls pizza, soda, and cookies to have during the workshops (which extended into their lunch hour).

\section{Researcher Response}

We felt it was our ethical duty to respond to the girls' concerns, which they reported during the third workshop. First, we discussed these incidents with the girls, educated them about backlash, and encouraged them to think of ways they wanted to handle the situation. [See Faludi (1991) for a thorough investigation of the concept of backlash and Shefer et al. (2008), for a recent discussion of resistance to gender role change in South Africa.] We supported the girls, affirmed their feelings, and expressed that it was not their responsibility to protect themselves from the boys' behavior. We asked the girls for their permission to talk about their concerns with the principal and/or teachers and said that we would protect their confidentiality by not naming any individuals. The girls agreed to have us discuss the incident and indicated that most of these incidents had been reported to teachers already.

We met with the principal to discuss what had been disclosed during the workshop. We were very concerned that the girls were being treated in such a way and did not want our program to create a new opportunity for the girls to be mistreated. We also learned that there was discontent from some of the professionals in the school (although the principal continued to actively support the program), and we wanted to address their concern as well. In collaboration with the principal, we discussed options for addressing the boys' behavior. We wanted to find a way to hear the concerns of the male students, without validating their disrespectful way of treating their female classmates.

After much discussion with the principal, it was decided that one researcher and two research interns would meet with the boys to talk about the program, hear their concerns, and express that the way the boys were interacting with the girls was inappropriate. The research team met with the $6^{\text {th }}$ grade boys (the girls were also present) and explained the purpose of the workshops. They listened to the boys' concerns (many of which involved the fact that the girls were "unfairly" getting pizza during the workshops). Two of the boys in the class were particularly hostile and expressed that they were entitled to pizza and said they were being treated unfairly compared to the girls. While most of the focus was on the tangible benefits of the program (e.g. food, journals), the boys sensed that the girls were getting some "other" benefit (that they struggled to articulate). The research team asked the boys if they would be interested in participating in a program for themselves. The general consensus at the conclusion of the discussion was that the boys would be interested in such a program.

The discussion took place during class time in which one female and male teacher were present. The school male social worker also requested to be in the meeting. The female teacher sat in the front of the classroom while the two men sat at the back of the room (near the co-investigator) and made fun of the program several times throughout the discussion. It was unclear whether the boys were able to hear these statements. When asked if they wanted to contribute publicly to the discussion, they declined. The principal later indicated to the lead researcher that both of the staff members had expressed some concerns about the program 
(although no specific issues were described, and the principal seemed undisturbed by their concerns). The site coordinator offered to meet with the staff members to discuss any questions they might have and made her contact information available to them. Unfortunately, neither of these staff members contacted the researcher, and the researchers were not informed of any specific or formal complaints. The researchers offered to implement a workshop for all the teachers and staff to explain the program and discuss the role they could play in promoting girls' resiliency, but the school did not participate in such a workshop.

We saw the potential benefits (to the girls and boys) of the boys having an opportunity to discuss their experiences with gender roles and patriarchy. Consequently, we developed a series of workshops for the boys and received approval from the Institutional Review Board to recruit. We utilized the same enrollment process, which was done for the girls. All the boys in the class were given a permission slip and parent letter to take home. Unfortunately, not a single boy in the class returned a signed permission form to be in the program. We do not know if the parents did not want their sons to participate or if the boys themselves chose not to return the forms. The girls' program was set up in such a way that the workshops took place in a separate room (not the girls' classroom); therefore, we did not have any direct contact with the boys and were unable to ask them why they did not return their forms. However, it was in stark contrast to the fact that every girl in the class was participating in the program designed for girls. We were aware that we had limited resources and wanted the boys to have access to other resources in the community, so we gave the principal contact information for other professionals who worked with boys'/men's issues and who would be interested in providing programming for the school. (To our knowledge, the school did not follow up on this referral.)

Although we were not able to implement a program for the boys or a workshop for the staff, we felt that the benefits of the program outweighed the potential risks of backlash. We took some measures in order to protect the girls. First and most importantly, we conveyed to the girls that their safety was our priority. We encouraged them to continue to have an open dialogue with us about their experiences and brainstormed ways they could deal with future experiences of gender prejudice. We also attempted to remove some of the motivations for the boys' jealousy. We ensured that the girls did not miss any classroom time and that the workshops only occurred during lunch and recess (although we continued to bring them food), and we discontinued the journal program.

\section{Discussion and Implications}

We learned a lot from our work with these girls, and it is difficult to condense our insights into one paper. We have identified three key lessons that we hope can be helpful for others doing social justice work. We pose these with the hope of furthering important dialogues about working with adolescent girls. We also include recommendations for an ideal system change approach to working with girls.

\section{Lesson 1: When working with girls, one must consider the systems in which they live, both at the micro and macro level.}

Social justice work with adolescent girls takes place within a sociocultural context influenced by multiple levels of systems (Bronfenbrenner, 1977; Kelly, 1970; Trickett, Kelly, \& Vincent, 1985). One important part of the system to which these girls belonged included their classroom and 
their interaction with male peers. During the workshops and the interviews at the end of $6^{\text {th }}$ grade, the girls reported experiencing multiple types of gender discrimination from their male peers. They indicated being excluded from activities, called derogatory names, and sexually harassed. These types of behaviors are typical of the ways in which children engage in discrimination towards their peers (Brown \& Bigler, 2004). Many young girls report experiencing overt, covert, and subtle forms of discrimination (Benokraitis, 1997) which can lead to a number of negative psychological consequences (Kaiser, Major, \& McKoy, 2004; Major, Barr, Zubek, \& Babey, 1999). The dynamics of this school system are important to consider as well. The female principal was incredibly supportive of the intervention and at the same time, some of the male adults expressed some opposition to the program.

We do not think that the reactions of the boys in this classroom were unique, but rather are indicative of a larger social system in which the girls live - namely a patriarchal system. The boys expected to be the center of attention and reacted strongly when they perceived the girls being given special consideration. And why wouldn't they? They are raised in a world that has taught them that "boyhood is the entitlement to and the anticipation of power" (Foster, Kimmel, \& Skelton, 2001) - at least for white, middle class, heterosexual boys. The boys' reactions were also not very surprising to the girls, given the fact that they were targets of gender prejudice from the boys in multiple ways. The boys in the class also outnumbered the girls almost two to one. While it is impossible to say what the interactions would have been like in a balanced classroom, or a classroom with more girls than boys, it is possible that being in the majority enhanced the boys' sense of entitlement and power. It is also likely that some of the boys were uncomfortable with the treatment of the girls, but they felt overpowered by other boys and were uncertain how to respond. Unfortunately, we were unable to work with the boys and only interacted with them during one meeting. Had they enrolled in the research study, we may have gained more insights into their experiences/perspectives about their interactions with the girls. As it stands, we draw tentative conclusions based on the girls' reports, our experiences with the boys in the meeting, and the body of research examining boys' gendered experiences. As action researchers dedicated to bettering the lives of girls, we must be aware of the systems in which girls live and design programs which consider the dynamics within these systems from the interactions with male peers, to the levels of support within a school, to the implications of patriarchy.

\section{Lesson 2: When doing programming for girls it is important to consider the multiple implications of an "empowerment" model.}

Interventions founded on the individual or interpersonal models of empowerment have provided valuable resources for ways to improve the lives of girls (e.g. Simmons, 2009; Wiseman, n.d.), and in many ways we developed our intervention with these forms of empowerment in mind. But, what happens when girls face backlash and resistance from others within a patriarchal system that does not respect their newfound empowerment? Although we sought to empower the girls in our program, they continued to experience backlash and sexism from their male peers. What happens when we as researchers are encouraging girls to have more voice, to speak up, and to build their self-esteem, and they are shut down by their male peers? Are we doing them a disservice? While we agree that girls should learn "to speak out against social cruelty and injustice" (Wiseman, n.d.), we are concerned about the lack of conversation about the potential consequences of speaking out against injustice. Is individual and interpersonal empowerment without societal empowerment a set-up for girls? 
As we planned and implemented this intervention, we faced challenges that others have likely struggled with. How do we develop a girl-centered intervention advocating for girls to be empowered to change themselves (and the world), without discounting the reality of the need for wider system change that girls cannot do by themselves? Rarely do interventions give girls the message that boys should be changing the system. While it is certainly a good thing to not tell girls that they are helpless victims (a message they receive in other areas of their lives), it is dangerous to convey to girls that they should feel solely responsible and accountable for changing a system that is not in their favor. We attempted to address these concerns by 1 ) discussing the boys' behaviors within the context of patriarchy; 2) asking the girls what actions they wanted to take and what they saw as potential costs or benefits of these actions; 3 ) addressing the boys' behavior with the school administration with the expectation that the school system should address the concerns; 4) meeting with the boys to discuss their behavior; and 5) offering to intervene directly by providing programming for the boys. We became aware how critical it is to address all implications of "empowerment" when implementing girls' programming and we continue to think about these concerns in our own work.

\section{Lesson 3: When doing action research, anticipate possible areas of resistance and make a plan with the community of participants about how it could be addressed.}

Of course, it is impossible to plan for everything, but some types of resistance or backlash might be anticipated. Any time one is doing research that challenges some type of status quo, they face the possibility of resistance from individuals who do not want to see the system change. In this case, the boys were resistant to the program for the girls. It was especially important to have an ally who held a position of power within the system (the school) and who was explicitly in support of the program. We were very lucky to have a supportive principal who worked with us to address this resistance and brainstorm possible solutions.

One way we responded to this resistance was to offer a program for the boys. We recognized the need to address system issues and the benefits that would come from such an intervention (for both the boys and the girls). In addition to improving the lives of the girls, we believe it is to boys' benefit to examine how they feel confined by gender roles and to view their female peers as respectable equals. Unfortunately, we experienced resistance when trying to provide programming for the boys, even after they requested it. For whatever reason, none of the boys ended up participating in our program. Perhaps programs for girls seem less threatening, or parents may be more inclined to allow their girls to be involved in a program designed to increase self-esteem and address the impacts of sexism than to let their boys participate in a program that increases self-esteem and examines gender stereotypes and their experiences of gender prejudice. Parents may be influenced by the dialogues regarding the "boy crisis" and have concern that any type of program addressing gender will necessarily be detrimental to boys. The boys themselves may have been resistant to being in the program. Although they expressed concern over the "unfairness" of the girls being in the intervention, they may not have really valued being in a program. As action researchers, how do we get boys invested in promoting social change and recognizing the benefits they would receive from that change? We fear that as long as some (e.g. Sommers, 2000) see social justice work as a process of taking (power, resources, authority) from some (i.e. boys and men) and giving it to others (i.e. girls and women), there will always be resistance to change. In the future, we would develop a 
plan in conjunction with our research site about how we might prevent or address such resistance if it does occur.

\section{An ideal Social Change Program}

Based on the lessons we learned from working with these girls, we have refined our ideas about what an ideal system change program would be. First of all, we think that it is essential that girls and boys participate in programs which address gender socialization, prejudice, and resiliency. We think that it is beneficial for them to engage in some joint programming (see Brinkman, et al. 2010 for an example of a co-ed program), but to also participate in programs which target the specific (and often different) concerns that are likely to be faced by boys and girls. We do not know if doing programming for boys and girls will decrease potential for backlash like the girls faced in this program. In fact, it is likely that (some) boys will resist a program which challenges their entitlement. In fact, an entire anti-feminist movement has evolved to resist such change (e.g. Gurian, 1996 ,1998; Gurian \& Stevens, 2005; Sommers, 2000, as described above). However, pro-feminist researchers and scholars have responded by asserting that the biological and essentialist arguments of male superiority (very often accompanied by arguments of "natural" male violence) are damaging for boys and men as well as girls and women and have called for programming for boys which challenges these assumptions (e.g. Kimmel, 1999; Lingard \& Douglas, 1999; Salisbury \& Jackson, 1996). We agree that boys and men will benefit from changing patriarchy and challenging limiting and restrictive messages about masculinity. It is important that programs for boys and men consider the possible resistance and ways to engage their audience. For example, Prime and Moss-Racusin (2009) identified key factors which increase men's awareness of gender bias, what motivates them to support social change and obstacles to their involvement, including fear and apathy. We agree with their assertion that a key to motivating men and boys to participate in change programs involves raising their awareness of the costs of gender bias and the benefits of gender equity to boys and men. Barker, Ricardo, and Nascimento, (2007) outline good practices for doing group education with boys based on evidence from program evaluations. They emphasize the discussion of the social construction of gender, the application of material to boys' everyday life, emphasis on skill building, and above all the creation of a safe environment where boys can think critically and express their opinions openly.

In an ideal approach, we would also address the school as a system. We would offer a staff training/workshop as part of the program. We believe that while it is unrealistic to think that all members of a school will support such resiliency programs, some staff members are supportive but may lack the knowledge of how best to do so. It is important to provide staff members with tools to promote equality. It is also important that the school conveys the message to the students that all members of the community are expected to treat each other with respect. In addition, researchers should create a system allowing school staff to convey any questions or concerns about programming occurring within the school.

In this case, we offered a program for the boys and for the school staff ad hoc, and neither were implemented. However, it is possible that developing these aspects as part of the program from the beginning could decrease some of the resistance from the boys and/or the staff and would work toward changing the school system. While this ideal scenario would provide an extensive system change approach, we recognize that it is not always possible to implement. Researchers may face barriers including limited economic resources, time, 
expertise (in working with girls and boys, teachers, etc.), and access to populations. We feel that even if a program cannot include all of these areas, it can be based on a system change theoretical orientation and can be beneficial. It is through this approach that we do not blame girls as victims or empower them as passive agents, but work to increase their resiliency while helping them recognize and change the systems which impact their lives.

\section{Conclusion}

In this paper, we describe our social justice intervention for adolescent girls and what we learned about the importance of system change when doing action research. What we have emphasized is that to truly improve the lives of girls, action research must acknowledge the complexity of the systems in which they live. This includes addressing the ways in which boys understand their position within the system and how that influences their interactions with girls. We advocate for girl-centered research that moves beyond the individual empowerment model to a broader model of empowerment that addresses the need for change within systems.

Contact information/Correspondence:

Britney G Brinkman

Counseling Psychology, Chatham University, Woodland Road, Pittsburgh, Pennsylvania, 15232;

email:bbrinkman@chatham.edu

\section{References}

AAUW (2008). Where the girls are: The facts about gender equity in education. Washington, D.C.: Author.

Barker, G., Ricardo, C. \& Nascimento, M. (2007) Engaging men and boys in changing genderbased inequity in health: Evidence from programme interventions. Geneva, World Health Organization. Available At:

http://whqlibdoc.who.int/publications/2007/9789241595490_eng.pdf

Benokraitis, N. (Ed) (1997) Subtle sexism: Current practice and prospects for change. Thousand Oaks: SAGE Publications.

Bigler, R. (1999) Psychological interventions designed to counter sexism in children: Empirical limitations and theoretical foundations. In W.Swann, J. Langlois, \& L. Gilbert (Eds.), Sexism and stereotypes in modern society. Washington, DC: American Psychological Association. 
Brinkman, B.G. \& Brinkman, K.G. (2004) Seeking self, the spiritual personality as a resiliency factor for young women. Paper presented at the annual meeting of the Association for Women in Psychology, Philadelphia, Pennsylvania.

Brinkman, B.G., Rosén, L. A., Zimmerman, T.S., Jedinak, A. (2010) Teaching children fairness: Decreasing gender prejudice amongst $5^{\text {th }}$ graders. Analyses of Social Issues and Public Policy, 10, 171-191. doi: 10.1111/j.1530-2415.2010.01222.x

Bronfenbrenner, U. (1977). Toward an experimental ecology of human development. American Psychologist, 32, 513-531. doi: 10.1037/0003-066X.32.7.513

Brown, C.S. \& Bigler, R.S. (2004). Children's perceptions of gender discrimination. Developmental Psychology, 40, 714-726. doi: 10.1037/0012-1649.40.5.714

Brown, L. M. (2003). Girlfighting: Betrayal and rejection among girls. New York, NY: University Press.

Brown, L.M., Chesney-Lind, M., \& Stein, N. (2007). Patriarchy matters: Toward a gendered theory of teen violence and victimization. Violence Against Women, 13, 1249-1273. doi: $10.1177 / 1077801207310430$.

Crooks, C.V. Goodall, G.R., Hughes, R., Jafe, P.G., \& Baker, L.L. (2007). Engaging men and boys in preventing violence against women: Applying a cognitive-behavioral model. Violence Against Women, 13, 217-239. doi: 10.1177/1077801206297336

Currie, D., Kelly, D. \& Pomerantz, S. (2009). "Girl power": Girls reinventing girlhood. New York, NY: Lang Publishing Inc.

Ditrano, C.J. \& Silverstein, L.B. (2006). Listening to parents' voices: Participatory action research in the schools. Professional Psychology: Research and Practice, 37, 359-366. doi: $10.1037 / 0735-7028.37 .4 .359$

Fabiano, P, Perkins, HW, Berkowitz, AB, Linkenbach, J \& Stark, C. (2003). Engaging men as social justice allies in ending violence against women: Evidence for a social norms approach. Journal of American College Health, 52, 105-112.

doi: $10.1080 / 07448480309595732$

Faludi, S. (1991). Backlash: The undeclared war against American women. New York, NY: Crown Publishers, Inc.

Findlen, B. (Ed.) (1995). Listen up: Voices from the next feminist generation. Seattle, WA: Seal Press.

Foster, V., Kimmel, M., Skelton, C. (2001). What about the boys? An overview of the debates. In Martino, W. \& Meyenn, B. (Eds.) What about the boys? Issues of masculinity in schools. Philadelphia, PA: Open University Press. 
Freeman, M. \& Mathison, S. (2009). Researching children's experiences. New York, NY: The Guilford Press.

Gilligan, C. (1982). In a different voice: Psychological theory and women's development. Cambridge, MA: Harvard University Press.

Gilligan, C. (1987), Moral orientation and moral development, in E. Kittay and D. Meyers (Eds.) Women and moral theory, (pp. 19-33). Totowa, NJ: Rowman \& Littlefield.

Glaser, B., \& Strauss, A. (1967). The discovery of grounded theory: Strategies for qualitative research. Chicago, IL: Aldine.

Gurian, M. (1996). The wonder of boys. New York, NY: Tarcher/Putnam.

Gurian, M. (1998). A fine young man. New York, NY: Tarcher/Putnam.

Gurian, M. \& Stevens, K. (2005). The minds of boys: Saving our sons from falling behind in school. San Francisco, CA: Jossey-Bass.

Hinshaw, S. (2009). The triple bind: Saving our teenage girls from today's pressures. New York, NY: Ballantine Books.

Husain, M. \& Millimet, D. (2008). The mythical 'boy crisis'? Economics of Education Review, 28(1) 38-48. doi:10.1016/j.econedurev.2007.11.002.

Jacob, I. (2002). My sisters' voices: Teenage girls of color speak out. New York, NY: Owl Books.

Jiwani, Y., Steenbergen, C., Mitchell, C. (Eds.) (2006). Girlhood: Redefining the limits. Montreal: Black Rose Books.

Johnson, A.G (1970). The gender knot: Unraveling our patriarchal legacy. Philadelphia, PA: Temple University Press.

Kaiser, C., Major, B., McKoy, S. (2004). Expectations about the future and the emotional consequences of perceiving prejudice. Personality and Social Psychology Bulletin, 30, 173-184. doi: 10.1177/0146167203259927

Kearney, M.C. (2009). Coalescing: The development of Girls' Studies. NWSA Journal, 21(1), 128.

Kelly, J. G. (1970). Toward an ecological conception of preventive interventions. In D. Aselson \& B. Kalis (Eds.), Community psychology and mental health (pp. 126-145). Scranton, PA: Chandler.

Kimmel, M. (1999). What are little boys made of? Ms., $9(6), 88-91$. 
Kimmel, M. (2010). Boys and school: Background paper on the "boy crisis. "Stockholm: Elanders Sverige AB.

Kindlon, D. \& Thompson, M. (1999). Raising Cain: Protecting the emotional life of boys. New York, NY: Ballantine.

Kidd, S.A. \& Kral, M.J. (2005). Practicing participatory action research. Journal of Counseling Psychology, 52, 187-195. doi: 10.1037/0022-0167.52.2.187

Kivel, P. (1999). Boys will be men. Philadelphia, PA: New Society Publishers.

Kramer, L (2011) The sociology of gender: A brief introduction ( $3^{\text {rd }}$ ed). New York/Oxford: Oxford University Press.

Lamb, L.M., Bigler, R.S., Liben, L.S. \& Green, V.A. (2009). Teaching children to confront peers' sexist remarks: Implications for theories of gender development and educational practice. Sex Roles, 61, 361-382. doi: 10.1007/s11199-009-9634-4

Lingard, B. \& Douglas, P. (1999). Men engaging feminisms: Pro-feminism, backlashes and schooling. Philadelphia, PA: Open University Press.

Maguire, P. (2001). Uneven ground: Feminisms and action research. In Reason, P. \& Bradbury, $\mathrm{H}$. (Eds.), Handbook of action research: Participative inquiry and practice, London: Sage Publications.

Major, B., Barr, L. , Zubek, J., Babey, S. (1999) Gender and self-esteem: Meta Analysis. In W. Swann, J. Langlois, \& L. Gilbert (Eds.), Sexism and stereotypes in modern society (pp. 223-253). Washington DC: American Psychological Association.

Mitchell, C. \& Reid-Walsh, J. (Eds.) (2005). Seven going on seventeen: Tween studies in the culture of girlhood. New York, NY: Peter Lang.

NCES (2010). The condition of education 2010. Washington, D.C.: Author.

Newman, D. M. (2007) Identities \& inequalities: Exploring the intersections of race, class, gender, and sexuality. New York, NY: McGraw-Hill.

Pipher, M. (1994). Reviving Ophelia: Saving the selves of adolescent girls. New York, NY: Pantheon.

Pollack, W. (1998). Real boys: Rescuing our sons from the myths of boyhood. New York, NY: Henry Holt.

Prime, J., \& Moss-Racusin, C.A. (2009). Engaging men in gender initiatives: What change agents need to know. New York, NY: Catalyst.

Rainey, A.B. \& Rust, J.O. (1999). Reducing gender stereotyping in kindergarteners. Early Child Development and Care, 150, 33-42. 
Ristock, J.L. \& Pennell, J. (1996). Community research as empowerment: Feminist links, postmodern interruptions. New York, NY: Oxford University Press.

Salisbury, J. \& Jackson, D. (1996). Challenging macho values. London: Falmer.

SAMHSA (1999). Girl Power! Is good mental health. Retrieved from http://mentalhealth.samhsa.gov/publications/allpubs/CA-0038/

Shandler, S. (1999). Ophelia Speaks: adolescent girls write about their search for self. New York, NY: Harper Perennial.

Shefer, T., Crawford, M., Strebel, A., Simbayi, L.C., Dwandwa-Henda, N., Cloete, A., Kaufman, M. R, \& Kalichman, S. C. (2008). Gender, power and resistance to change among two communities in Western Cape, South Africa. Feminism \& Psychology, 18, 157-182. doi: $10.1177 / 0959353507088265$.

Simmons, R. (2009). The curse of the good girl: Raising authentic girls with courage and confidence. New York, NY: The Penguin Press.

Steese, S., Dollette, M., Philips, W., Hossfield, E., Matthews, G. \& Taormina, G. (2006). Understanding girls' circle as an intervention on perceived social support, body image, self-efficacy, locus of control, and self-esteem. Adolescence, 41, 55-74.

Sommers, C. H. (2000). The war against boys: How misguided feminism is harming our young men. New York, NY: Simon \& Schuster.

Tolman, D., \& Porche, M. (2000). The adolescent femininity ideology scale; development and walidation of a new measure for girls. Psychology of Women Quarterly, 24, 365-376. doi: $10.1111 /$ j.1471-6402.2000.tb00219.x

Trickett, E. J., Kelly, J. G.,\& Vincent, T. A. (1985). The spirit of ecological inquiry in community research. In E. Susskind \& D. Klein (Eds.), Community research: Methods, paradigms, and applications. New York, NY: Praeger.

Turner, S., Norman, E. \& Zunz, S. (1995) Enhancing resiliency in girls and boys: A case for gender specific adolescent prevention programming. The Journal of Primary Prevention, 16, No 1. doi: 10.1007/BF02407231

Weaver-Hightower, M. (2003) The "Boy Turn" in research on gender and education. Review of Educational Research, 73, 471-498. doi: 10.3102/00346543073004471

Whitmire, R. (2010). Why boys fail: Saving Our sons from an educational system that's leaving them behind. New York, NY: AMACOM.

Wiseman, R. (n.d.) The owning up program. Retrieved from http://rosalindwiseman.com/owning-up/ 